\title{
The Eerdmans Dictionary of Early Judaism
}

\author{
J. J. Collins \\ D. Harlow
}

Angela Kim Harkins

Fairfield University, aharkins@fairfield.edu

Follow this and additional works at: https://digitalcommons.fairfield.edu/religiousstudies-books Copyright 2010 Eerdmans

Content archived here with permission from the copyright holder.

\section{Recommended Citation}

Collins, J. J.; Harlow, D.; and Harkins, Angela Kim, "The Eerdmans Dictionary of Early Judaism" (2010). Religious Studies Faculty Book Gallery. 11.

https://digitalcommons.fairfield.edu/religiousstudies-books/11

This item has been accepted for inclusion in DigitalCommons@Fairfield by an authorized administrator of DigitalCommons@Fairfield. It is brought to you by DigitalCommons@Fairfield with permission from the rightsholder(s) and is protected by copyright and/or related rights. You are free to use this item in any way that is permitted by the copyright and related rights legislation that applies to your use. For other uses, you need to obtain permission from the rights-holder(s) directly, unless additional rights are indicated by a Creative Commons license in the record and/or on the work itself. For more information, please contact digitalcommons@fairfield.edu. 


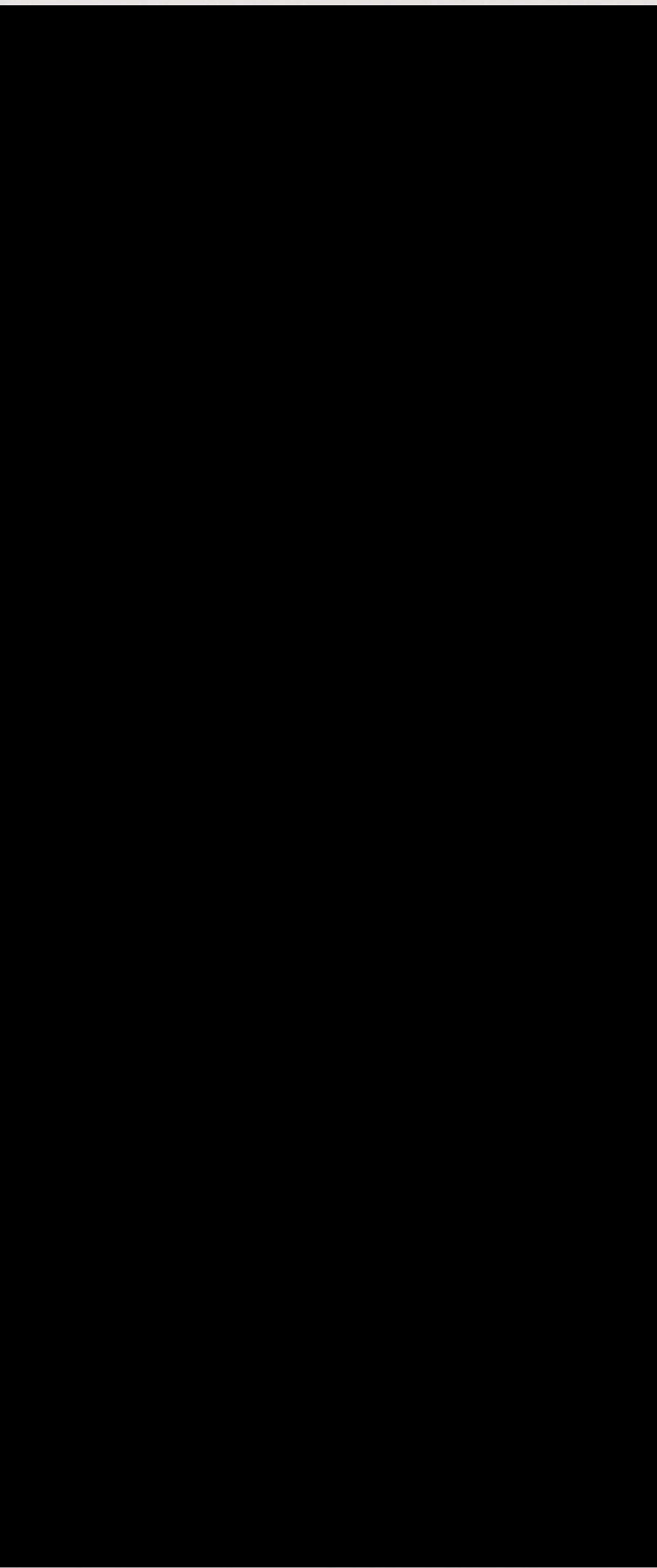

this category offers insight into the complex process of scripturalization that developed during this period. These deeply human expressions of joy or despair directed to God were transformed into sacred Scripture fundamentally understood to be from God (Kugel 1986). Part of this process involved cloaking the new composition within an authoritative guise by using classic biblical phraseology and traditional interpretive motifs (Newman 1999). For example, Neh. 9:6-31 makes strong use of biblical imagery, specifically Deuteronomic language and motifs interspersed with Priestly elements, in its rehearsal of salvation history in vv. 5-31, concluding with a petition that appeals to God's graciousness and mercy in vv. 32-37. Similarly, the prayer in Jdt. 9:214 makes use of biblical language and motifs from Exodus 15 and Genesis 34 .

Hymns, prayers, and psalms from the Second Temple period make extensive and varied use of scriptural allusions and may also employ exegetical maneuvers similar to those found in biblical texts. The intentional use and redeployment of Scripture is not a sign of the lack of creativity of these ancient authors but a feature of a complex process that functions to authorize these compositions by associating them with the authority of older texts (Najman 2003). The authors freely drew upon a number of compositional techniques. These include quoting or alluding to distinct biblical passages, modeling new compositions on one or more biblical passages, creating a chain of quotations in the style of a florilegium, assembling a pastiche of biblical quotations and allusions into a new composition, and freely composing new compositions based on traditional biblical motifs or images.

\section{Formal Categorization and Literary Styles}

In classifying this body of literature, problems arise when formal categories and literary styles are derived from biblical exemplars. Postbiblical hymns, prayers, and psalms have often been described in light of preexisting literary categories formulated from classical Hebrew models, resulting in characterizations that cast later writings as imitations of varying degrees or as mixed forms. Scholarly descriptions of postbiblical compositions as "hybrid" forms are unsatisfying and sometimes reflect a modern lack of familiarity with ancient compositional techniques. The limitations of using categories based on classical biblical exemplars are especially apparent in the case of the hymns, prayers and psalms discovered at Qumran, many of which had not been previously known. Indeed, categories exert powerful influence over how texts are understood, yet in the case of hymns, prayers, and psalms the categories themselves are shifting and are not consistently defined in the scholarly literature.

In a similar fashion, the literary styles of postbibli-

Various developments in the scholarly understanding of late Second Temple hymns, prayers, and psalms have taken place in the last several decades. These advances owe in part to the discovery and study of the Qumran texts, which sparked a renewed interest in the literature of early Judaism. Study of the texts that fall broadly into cal poetical and liturgical writings have often been assessed on expectations formed from classical biblical Hebrew poetry rather than from comparisons with contemporaneous writings. This has resulted in unhelpful characterizations of Second Temple writings, which often freely used biblical images and language, as imita- 
tions of varying degrees of success. One example of this comes from the book of Sirach, which when compared with the literary style found in the classical Hebrew book of Proverbs was found to be deficient in one way or another. These expectations also colored how the first generation of Scrolls scholars viewed these newly discovered writings. Early assessments of the poetic style of the Hodayot reflect a bias toward classical biblical forms and style, so much so that the Qumran style was described early on as "very poor poetry characterized by irregular meter, rather weak use of parallelism, frequent and monotonous repetition of words, and the apparent absence of any firm principle of construction" (Thiering 1963). These scholarly perceptions rightly appear outdated to readers today. Such an approach fails to do justice to the particular aspects of poetry of this time, particularly in light of the developments taking place in the current scholarly understanding of the processes of scripturalization and canonization in the Second Temple period.

A number of questions remain about the relationship between hymns, prayers, and psalms during the late Second Temple period to other writings of that time. Their appearance throughout Jewish apocalypses, the prominence of wisdom motifs within them (e.g., 1QH; Bar. 3:9-4:4), and their precise role in the liturgy and worship of the late Second Temple period have yet to be fully studied.

\section{Drawing Distinctions between Hymns, Prayers, and Psalms}

The traditional scholarly conceptualization of categories based on classical Hebrew types typically distinguishes between the manner of performance of these types, identifying "hymns" as sung poetic compositions that praise God, "psalms" as poetic liturgical compositions, and "prayers" as recited prose compositions.

Of the three categories prayer is perhaps used most loosely to refer inclusively to any communication between humanity and God. There are many ways scholars have attempted to restrict the broad understanding of prayer as any communication between humanity and God. The first of these attempts limits this category to prose compositions and not poetry (into which would fall "hymns" and "psalms"). Even so, some scholars have even expanded the idea of prayer to include every type of poetry used in the worship of God. This standard approach of distinguishing literature on the basis of prosaic or poetic characteristics may wrongly presume that the distinction between prose and poetry in the ancient world strictly followed such literary conventions at all (Kugel 1981). The category of prayer has also been restricted to petition and not praise. Such a range in meaning of the idea of prayer may have also been understood in the ancient world. Plato evidently viewed prayer primarily as petition (Politics 290d), while both Philo and Origen presumed prayer to include both petition and praise (Philo, Spec. Leg. 1.224 and De Plantatione 135; Origen, On Prayer 14.2). Furthermore, it is possible to distinguish between various understandings of petition and praise, depending upon their dif- ferent purposes. Yet another attempt to delimit prayer texts may specify that they include only the secondperson address to God, while "hymns" or "psalms" may be composed in either third-person or second-person address to God. These issues are further complicated by the question of whether or not a prayer composition actually functioned as a means of communicating with God, as it is possible that its composition may have been for a literary purpose.

Prayer includes the following distinct elements: a sender, a message, and a purpose. This purpose may be to seek results or to maintain relationships. The sender may be an individual or a community, and the message may be one of praise, thanksgiving, lament, petition, or contrition. One challenge to the study of prayer in early Judaism is that prior to the discovery of the Dead Sea Scrolls, relatively few written prayer texts survived in any significant degree prior to the ninth-century Jewish copies of the Siddur. From what can be pieced together from the prayer texts at Qumran, the community of the Dead Sea Scrolls had a rich prayer life that included morning and evening prayers as well as daily and Sabbath prayers. Examples of collections of these prayers are The Daily Prayers (4Q503), Words of the Luminaries (4Q504), and the Songs of Sabbath Sacrifice (4Q400-407, 11Q17). Among the interesting themes that appear in these early prayer texts is that of praying with or like the angels (4Q503) and prayer as a sacrificial offering apart from the Temple cult (1QS 9:4-5) (Schuller 2000). How much of this can be extended to early Christian and contemporary Jewish practice is not clear at this time, although some have argued in favor of seeing at least some of the Qumran prayer texts as presectarian in origin (4Q504).

Strictly literary studies of prayer literature from this time period may be enriched by social-scientific approaches that examine these texts from a cross-cultural perspective with a focus on the phenomenon of communication (Malina 1980). Malina's definition of prayer is as follows: "a socially meaningful act of communication, bearing directly upon persons perceived as somehow supporting, maintaining, and controlling the order of existence of the one praying, and performed with the purpose of getting results from or in the interaction of communication" (Malina 1980: 215). The five elements of prayer according to this model include (1) the sender (either an individual or a group); (2) the message (petition, adoration, contrition, or thanksgiving); (3) the medium of the prayer (verbal and nonverbal forms of communication of many types); (4) the recipient (God); and (5) the purpose or the results that are sought (Malina 1980).

One area of growing interest in recent scholarship is the proliferation of confessional and penitential prayer during the Second Temple period (Werline 1998; cf. Bautch 2003). The biblical penitential psalms category (Psalms 6, 32, 38, 51, 102, 130, and 143) was traditionally classified as part of the broader group of lament psalms by Gunkel (1933). Yet, with the exception of Psalm 51, not all of these were thought by him to exhibit strong penitential content. Instead, this category 
was a remnant of medieval theological readings of them. Scholarship on this type of literature was reconceptualized with the work of Westermann and his theological discussion of the influence of Deuteronomic theology upon the form of the lament (Westermann 1981). Pure lament and complaint against God becomes impermissible in light of the growing Deuteronomic emphasis on the guilt of Judah's disobedience. Recent scholarly understandings of penitential prayer have tended to move away from a strictly form-critical approach in favor of a traditio-historical perspective that takes into account the impact of these theological and ideological influences from the Second Temple period.

Penitential prayers are characterized by the following elements: confession of sins, acknowledging that God's judgment is just, rehearsal of God's mercy in history; and a concluding appeal to God for mercy in the current context (see Ezra 9:6-15, Neh. 1:5-11 and 9:6-37, and Dan. 9:4-19; Pr. Azar. 1:3-22; Words of the Luminaries frg. 1-2 lines 5-7; Communal Confession [4Q393]). More importantly, current scholars recognize how a wide range of social settings, including contemporary experiences like the Holocaust, and a variety of literary contexts, as well as performance, all contribute to the shaping of modern understandings of genre (Nasuti 1999).

\section{Hymns and Psalms}

Both hymns and psalms are sung poetic compositions and so will be discussed together. These texts may be embedded in other literature and also found in collections (Psalter, Psalms of Solomon, Hellenistic Synagogal Prayers, Odes of Solomon, 1QH). Hymns proper are specified as poetic compositions sung in praise of God. In classic literary studies of these texts, hymns may be understood as a specific type of the larger category of psalms. While psalms are also loosely discussed in the scholarly literature, perhaps the best place to begin is with the classic understandings of these terms. Hermann Gunkel (1933), in his classic formulation of formcritical categories for the biblical psalms, identified seven types: hymns of praise, laments (including psalms of trust and thanksgiving psalms), royal psalms, wisdom psalms, liturgical psalms, and historical psalms. Gunkel's form-critical work presumed that these literary types originated in a cultic context, and this operative assumption continued in the work of Sigmund Mowinckel, who examined the biblical forms from the perspective of the wider ancient Near Eastern literary context (Mowinckel 1962).

The presumed relationship between the Temple cult and literary form is far less certain in the current scholarly study of the hymns, prayers, and psalms dated from the time of Alexander's conquest through the Bar Kokhba Revolt (ca. 321 B.C.E.-135 C.E.). While older scholarship may have confidently situated this type of literature within a specific context of worship, the automatic relationship between prayer literature and the cult is less frequently assumed today. If the role of the biblical psalms in the Temple worship is unclear, it is all the more unclear what liturgical function nonbiblical psalms and hymns might have enjoyed outside of a Temple context. It may be said, however, that broad statements suggesting that the rise of prayer literature during the late Second Temple period was a sign that prayer was replacing Temple sacrifice are inadequate in accounting for all of the varied developments taking place during this time. The relationship between prayer literature and the sacrificial cult is far more nuanced and complex than has been previously thought (Falk 2000), and far too broad a topic to treat adequately here. Clearly the scholarly understanding of the poetic and liturgical compositions during this period is complicated by the many unanswered historical questions about the nature of the composition of these writings and the experience of these texts within the cult.

\section{Literary Contexts}

\section{Apocrypha and Pseudepigrapha}

Hymns, prayers, and psalms are well represented in the apocryphal and pseudepigraphal literature. Because they are discrete anonymous compositions that make use of stereotypical language, and are easily moved from one literary context to another, questions concerning their provenance and authorship are difficult to answer. This mobility may also complicate the identification of which literary context is primary and which is secondary. Some examples of these "floating" compositions that have multiple literary contexts include the prayer found in both Baruch 5 and the Psalms of Solomon 11. Another example of this phenomenon is the apocryphal Psalm $151 \mathrm{~A} / \mathrm{B}$, known only in Greek, Latin, and Syriac manuscripts, which may be included in the Qumran scroll 11QPs ${ }^{\mathrm{a}}$, although the particular form found at Qumran has significant variations. Independent hymns, prayers, and psalms originally composed for and embedded in narrative contexts may have found their way into liturgical use. At the same time, those compositions that may have begun as liturgical writings may have been absorbed into different literary contexts at later times. A significant number of penitential prayers and confessions are found embedded in narrative contexts (e.g., Ezra 9:6-15; Neh. 9:6-37; Dan. 9:4-19; Jdt. 9:2-14; Tob. 3:2-6, 11-15; Add. Esth. 13:9-17; 14:3-19; Bar. 1:15-3:8; 2 Bar. 48:2-24; 54:1-22; 1 Macc. 3:50-53; 4:30-33; 3 Macc. 2:2-20; 6:2-15; Jub. 10:3-6; Joseph and Aseneth 12-13; Prayer of Manasseh; Josephus, Ant. 4.3.2; 2.16.1). While it is difficult to determine with certainty if these hymns, prayers, and psalms were primarily liturgical or literary, compositions embedded in literary contexts often fit well the plot and progression of the larger narrative context (Chesnutt and Newman 1997).

\section{Dead Sea Scrolls}

A wide-ranging collection of hymns, prayers, and psalms constitutes a significant portion of the total number of manuscripts catalogued from the Qumran discovery. Approximately 200 nonbiblical psalms and prayer texts, including many not previously known to scholars, have been counted. Even so, there was little indication during the first twenty-five years of Scrolls 
scholarship that hymns, prayers, and psalms would constitute such a significant proportion of the literature from Qumran, and even now much work in analyzing these finds remains to be done (Schuller 1994: 156).

While no complete copy of the Psalter was found at Qumran, the book was well represented among the biblical books, numbering 39 copies and including manuscripts found in Qumran Caves 1, 2, 3, 5, 6, 8, and 11, Nahal Hever, and Masada. Many of the nonbiblical hymns, prayers, and psalms identified at Qumran appear in various literary contexts. In addition to collections (Songs of Sabbath Sacrifice and Hodayot), they appear embedded in various types of works such as the rule texts (1QS 10) and in a number of pseudepigraphic writings (prayers of Abraham in 1QapGen, of Levi in 4QTLevi ar $^{\mathrm{b}}$, and of Joseph in 4Q372, and prayers in copies of Tobit and Jubilees) (Chazon and Bernstein 1997).

According to Schuller, there are many reasons why this body of literature has been among the slowest of the Qumran texts to be explored to a full degree even sixty years after their discovery (Schuller 2004: 412-15). The primary challenge of working with this type of literature was the poor condition of the texts themselves. Much of the early work on these texts sought to prepare an editio princeps and demanded specialized skills. Reconstructions of texts were based on a careful study of the material aspects of fragments since there was no literary exemplar. For various reasons peculiar to this scroll, a revised critical edition of the large collection of compositions known as the Hodayot from Cave 1 appeared only in 2009. This particular collection of writings unknown to scholars prior to 1947 , has been classified at different times as hymns and as psalms. It was not until much later that scholars began systematically studying these compositions from a literary and theological perspective. Even today, sixty years after their discovery, there remains much work to be done with this literature from Qumran.

One challenge to studying this type of literature from Qumran is the classification of writings into sectarian or nonsectarian and liturgical or nonliturgical. While it was commonly assumed in the early generation of scholarship on the Scrolls that anything nonbiblical was automatically deemed sectarian, today the discussion of sectarian classification continues with far more nuance. Scholars are increasingly reluctant to assign a sectarian designation to texts since it is possible for a text to be authored by one community and used later by another. It is also conceivable for sectarian authors to have composed nonpolemical writings. Problems with classification continue with the discussion of the liturgical or nonliturgical status of some of the compositions from Qumran, although here the presence of explicit marks of liturgical usage may make some easier than others to identify. These signs may include the use of the first-person plural and internal reference to a particular liturgical occasion. Liturgical use may also be indicated by the presence of formulaic elements such as "and they shall answer and they shall say," as may be seen in the case of $4 \mathrm{Q} 503,4 \mathrm{Q} 266$, and $4 \mathrm{Q} 286$. The thirteen Songs of the Sabbath Sacrifice have been situated by most scholars within the liturgical cycle of one quarter of a full year. Other texts that have been argued to be a presectarian liturgical composition are $4 Q D i b H a m$, the collection of daily prayers (4Q503), and festival prayers (4Q507-9; 1Q34) (Chazon 1992).

\section{Early Christian Literature}

Many hymns, prayers, and psalms found in early Christian literature bear a strong resemblance to Jewish forms, exhibiting literary features such as parallelism and extended descriptions commonly found in Hebrew poetical and liturgical writings (e.g., the Magnificat [Luke 1:46-55], the Benedictus [Luke 1:68-79], and the Nunc Dimittis [Luke 2:29-32]). Fragments of longer hymnic compositions appear in the Pauline corpus (Eph. 5:14; 1 Tim. 3:16 and 6:15-16; 2 Tim. 2:11-13; Titus 3:4-7; Phil. 2:6-11) and in the book of Revelation (1:4-8; $4: 8,11 ; 5: 9-10,12 ; 11: 15,17-18 ; 15: 3-4 ; 22: 17)$. These hymnic fragments may include liturgical or doctrinal emphases.

Syriac literature provides a particularly rich source of information about hymns, prayers, and psalms in early Christianity. Early collections of Christian poetical literature that may have had a liturgical background include the Odes of Solomon, which are dated to approximately the second century C.E. in Syria. These writings have survived in Greek and Syriac, with a few compositions having been absorbed into the Greek Pistis Sophia, an early Gnostic work (Brock 1979). Both these and the hymns written by Ephrem the Syrian (d. 373) are notable for their rich imagery and use of Scripture. Both doctrinal and liturgical emphases are obvious in Ephrem's hymns, and their exegetical maneuvers were long noted as being like those found in Jewish interpretative writings. An example of early Christian prayer texts is found in the Acts of Thomas, which was written in Syriac but later translated into Greek. This text contains a number of prayers of interest for the study of the development of Christian baptismal liturgy as they provide evidence for the practice of anointing baptism. Much remains to be done in the study of how the hymns, prayers, and psalms in early Christian writings may be related to the developments observed in early Jewish literature.

\section{BIBLIOGRAPHY}

R. J. BAUTCH 2003, Developments in Genre between PostExilic Penitential Prayers and the Psalms of Communal Lament, Atlanta: Scholars Press. - S. P. BROCK 1979, The Holy Spirit in the Syrian Baptismal Tradition, Poona: Anita Printers. • E. G. CHAzON 1992, "Is Divrei ha-me'orot a Sectarian Prayer?" in The Dead Sea Scrolls: Forty Years of Research, ed. D. Dimant and U. Rappaport, Leiden: Brill, 3-17. - E. G. ChAzON AND M. J. BeRnstein 1997, "An Introduction to Prayer at Qumran," in Prayer from Alexander to Constantine, ed. M. Kiley et al., New York: Routledge, 9-13. • R. D. CHESNUTT AND J. NEWMAN 1997, "Prayers in the Apocrypha and Pseudepigrapha," in Prayer from Alexander to Constantine, ed. M. Kiley et al., New York: Routledge, 38-42. • D. FALK 2000, "Qumran Prayer Texts and the Temple," in Sapiential, Liturgical and Poetical Texts from Qumran, ed. D. K. Falk, 
F. García Martínez, and E. M. Schuller, Leiden: Brill. • H. GUNKEL 1933, Einleitung in die Psalmen: Die Gattungen der religiösen Lyrik Israels, Göttingen: Vandenhoeck \& Ruprecht. • J. L. KUGEL 1981, The Idea of Biblical Poetry, Baltimore: Johns Hopkins University Press. - B. J. MALINA 1980, "What is Prayer?" TBT 18: 214-20.・S. MOWINCKEL 1962, The Psalms in Israel's Worship, New York: Abingdon; rpt. Grand Rapids: Eerdmans, 2004. • H. NAJMAN 2003, Seconding Sinai: The Development of Mosaic Discourse in Second Temple Judaism, Leiden: Brill. • H. P. NASUTI 1999, Defining the Sacred Songs: Genre, Tradition, and the Post-Critical Interpretation of the Psalms, Sheffield: Sheffield Academic Press. - J. H. NEWMAN 1999, Praying by the Book: The Scripturalization of Prayer in Second Temple Judaism, Atlanta: Scholars Press. • J. H. NEYREY 2007, Give God the Glory: Ancient Prayer and Worship in Cultural Perspective, Grand Rapids: Eerdmans. • E. M. SCHuller 1994, "Prayer, Hymnic, and Liturgical Texts," in The Community of the Renewed Covenant: The Notre
Dame Symposium on the Dead Sea Scrolls, ed. E. Ulrich and J. VanderKam, Notre Dame: University of Notre Dame Press, 153-71. • E. M. SCHULleR 2000, "Petitionary Prayer and the Religion of Qumran," in Religion in the Dead Sea Scrolls, ed. J. J. Collins and R. A. Kugler, Grand Rapids: Eerdmans, 29-45. - E. M. SCHuller 2004, "Prayer at Qumran," in Prayer from Tobit to Qumran, ed. R. Egger-Wenzel and J. Corley, Berlin: de Gruyter, 411-28. - E. M. SCHULlER 2006, "Prayers and Psalms from the Pre-Maccabean Period," DSD 13: 306-18. • H. Stegemann with E. SCHuller 2009, Qumran Cave 1.III: 1 QHodayot $^{a}$, with Incorporation of 1 QHodayot $^{b}$ and 4QHodayot ${ }^{a-f}$, DJD 40 , Oxford: Clarendon. - B. THIERING 1963, "The Poetic Forms of the Hodayot," JSS 8: 189-209. • C. WESTERMANN 1981, Praise and Lament in the Psalms, trans. K. R. Crim and R. N. Soulen, Atlanta: John Knox. • R. A. WERLINE 1998, Penitential Prayer in Second Temple Judaism: The Development of a Religious Institution, Atlanta: Scholars Press. 